\title{
PENGARUH SIKAP DAN MOTIVASI SISWA TERHADAP HASIL BELAJAR MATEMATIKA SISWA KELAS VII SMPN 12 KENDARI TAHUN PELAJARAN 2017/2018
}

\author{
Burhanuddin $^{\text {I) }}$ Muhammad Sudia ${ }^{2)}$, La Arapu ${ }^{3)}$ \\ ${ }^{1}$ alumni Jurusan Pendidikan Matematika, ${ }^{2,3}$ Dosen Jurusan Pendidikan Matematika \\ FKIP Universitas Halu Oleo Email: burhanmaliono354@ gmail.com ; \\ Muhammad_matematika@yahoo.co.id ; laarapu@gmail.com .
}

\begin{abstract}
Abstrak
Jenis penelitian ini adalah ex post facto, Tujuan penelitian ini untuk mengetahui (1) Deskriptif sikap, motivasi dan hasil belajar matematika siswa kelas VII SMP Negeri 12 Kendari, (2) Pengaruh sikap siswa terhadap hasil belajar matematika siswa kelas VII SMP Negeri 12 Kendari, (3) Pengaruh motivasi siswa terhadap hasil belajar matematika siswa kelas VII SMP Negeri 12 Kendari, (4) Pengaruh sikap dan motivasi siswa secara bersama-sama terhadap hasil belajar matematika siswa kelas VII SMP Negeri 12 Kendari. Berdasarkan hasil analisis regresi linear berganda data sikap siswa pada pelajaran matematika $\left(\mathrm{X}_{1}\right)$ dan motivasi siswa pada pelajaran matematika $\left(\mathrm{X}_{2}\right)$ secara bersamasama terhadap hasil belajar matematika siswa $(\mathrm{Y})$ diperoleh persamaan regresi $\hat{\mathrm{Y}}=-10,559+0,689 \mathrm{X}_{1}$ $+0,190 \mathrm{X}_{2}$ dan nilai koefisien determinasi $\mathrm{R}^{2}=0,898$. Berkesimpulan bahwa sikap dan motivasi siswa pada pelajaran matematika berpengaruh positif yang signifikan terhadap hasil belajar matematika siswa SMP Negeri 12 Kendari.
\end{abstract}

Kata Kunci: sikap, motivasi, hasil belajar matematika

\section{THE INFLUENCE OF STUDENTS 'ATTITUDES AND MOTIVATIONS ON CLASS VII STUDENTS' MATHEMATICS LEARNING OUTCOMES OF SMPN 12 KENDARI 2017/2018 ACADEMIC YEAR.}

\begin{abstract}
This type of research is ex post facto. The purpose of this study is to find out (1) Descriptive attitudes, motivation and mathematics learning outcomes of grade VII students of SMP Negeri 12 Kendari. (3) The effect of student motivation on mathematics learning outcomes of grade VII students of SMP Negeri 12 Kendari, (4) The influence of students' attitudes and motivation together on the mathematics learning outcomes of grade VII students of SMP Negeri 12 Kendari. Based on the results of multiple linear regression analysis of student attitudes data on mathematics (X1) and student motivation in mathematics (X2) together with students' mathematics learning outcomes (Y) obtained by the regression equation $\hat{Y}=-10,559+0,689 \mathrm{X} 1+0,190 \mathrm{X} 2$ and coefficient of determination $\mathrm{R} 2=$ 0.898. Concluding that the attitudes and motivation of students in the mathematics lesson had a significant positive effect on the mathematics learning outcomes of students of SMP Negeri 12 Kendari.
\end{abstract}

Keywords: attitude, motivation, mathematics learning outcomes. 


\section{Pendahuluan}

Secara umum pendidikan dipandang sebagai faktor utama dalam bidang pembangunan, pandangan ini mengandung suatu pengertian bahwa pendidikan dapat memotori dan menopang proses pembangunan. Pembangunan secara menyeluruh. Hal ini didasarkan atas pemikiran bahwa di samping memperoleh pendidikan yang dianggap sebagai hak asasi, juga pendidikan yang merata bagi setiap warga akan meningkatkan kemampuan berfikir tinggi serta dapat menambah taraf hidup ke arah yang lebih maju. Salah satu upaya untuk meningkatkan pembangunan di bidang pendidikan adalah upaya meningkatkan mutu pelaksanaan proses belajar di sekolah.

Secara psikologis belajar merupakan suatu proses perubahan yaitu perubahan tingkah laku sebagai hasil dari interaksi dengan lingkungannya dalam memenuhi kebutuhan hidupnya. Perubahan-perubahan tersebut akan nyata dalam seluruh aspek tingkah laku (Slameto, 2015: 2). Menurut Winkel yang dikutip oleh Hallen (2005:32) belajar adalah suatu aktivitas mental/psikis yang berlangsung dalam interaksi langsung dengan lingkungannya, yang menghasilkan perubahan-perubahan dalam pengetahuan, pemahaman, keterampilan dan nilai sikap. Perubahan itu berlangsung secara relatif konstan dan berbekas. Perubahan yang diperoleh seseorang setelah melalui suatu proses belajar meliputi perubahan keseluruhan tingkah laku. Jika seseorang belajar sesuatu, sebagai hasilnya ia akan mengalami perubahan tingkah laku secara menyeluruh dalam sikap, keterampilan, pengetahuan dan sebagainya (Slameto, 2015: 4-5).

Penyelenggaraan pendidikan di sekolah dilakukan melalui proses belajar mengajar. Keberhasilan siswa dalam mempelajari materi pelajaran dinyatakan dengan hasil belajar. Hasil belajar sebagai indikator keberhasilan pembelajaran merupakan salah satu problematika yang tidak pernah habis dibahas dalam dunia pendidikan. Siswa sebagai subjek dalam pembelajaran memiliki hasil belajar yang berbeda-beda.

Menurut Sudjana (2016: 22), hasil belajar adalah kemampuan-kemampuan yang dimiliki siswa setelah ia menerima pengalaman belajarnya. Hasil belajar dapat muncul dalam berbagai jenis perubahan atau pembuktian tingkah laku seseorang. Selanjutnya menurut
Slameto (2015: 2) menyatakan "hasil belajar adalah suatu proses usaha yang dilakukan seseorang untuk memperoleh suatu perubahan tingkah laku yang baru secara keseluruhan sebagai hasil pengalamannya sendiri".

Hasil belajar adalah sesuatu yang diperoleh setelah melakukan kegiatan belajar. Hasil belajar diperoleh setelah diadakannya evaluasi. Mulyasa (2007: 255) menyatakan bahwa "evaluasi hasil belajar pada hakikatnya merupakan suatu kegiatan untuk mengukur perubahan perilaku yang telah terjadi". Hasil belajar ditunjukkan dengan prestasi belajar yang merupakan indikator adanya perubahan tingkah laku siswa.

Keragaman karakteristik hasil belajar yang dicapai siswa sesungguhnya bersinggungan langsung dengan banyak faktor. Menurut Hallen (2005: 118), keadaan ini biasanya dilatar belakangi oleh aspek motivasi, minat, sikap, kebiasaan belajar, ciri-ciri kepribadian tertentu ataupun pola-pola pendidikan yang diterima dari orang tua dan suasana keluarga yang tidak mendukung.

Matematika merupakan salah satu mata pelajaran yang kurang diminati oleh siswa. Menurut Sriyanto (2004:12), anggapananggapan negatif dari sebagian besar siswa mengenai mata pelajaran matematika sebagai mata pelajaran yang sulit tidak terlepas dari persepsi yang berkembang dalam masyarakat tentang matematika. Persepsi negatif itu ikut dibentuk oleh anggapan bahwa matematika merupakan ilmu yang penuh dengan lambanglambang dan rumus yang sulit dan membingungkan. Anggapan ini muncul atas pengalaman kurang menyenangkan ketika belajar matematika di sekolah. Akibatnya, pelajaran matematika tidak dipandang objektif lagi. Hal ini berimbas pada rendahnya kualitas hasil belajar matematika siswa dalam mempelajari bidang studi tersebut.

Sikap merupakan kecenderungan atau kesediaan seseorang untuk bertingkah laku tertentu kalau ia menghadapi rangsangan tertentu (Wirawan, 2002). Menurut Robert R. Gade (dalam Siskandar, 2008: 440), sikap merupakan kesiapan yang terorganisir yang mengarahkan atau mempengaruhi tanggapan individu terhadap objek. Sikap dapat pula bersifat positif dan dapat pula bersifat negatif (Heri Purwanto dalam Wawan dan Dewi, 2010:34). Hal senada diungkapkan oleh Syah (2004:135) bahwa sikap adalah gejala internal yang berdimensi afektif 
berupa kecenderungan untuk mereaksi atau merespons (response tendency) dengan cara yang relatif tetap terhadap objek, orang, barang, dan sebagainya baik secara positif maupun negatif.

Jihat dan Haris (2008) berpendapat bahwa sikap bermula dari perasaan (suka atau tidak suka) yang terkait dengan kecenderungan seseorang dalam merespons sesuatu/objek. Sikap juga sebagai ekspresi dari nilai atau pandangan hidup yang dimiliki oleh seseorang. Menurut Berkowitz dalam (Azwar, 2016:5), sikap seseorang terhadap suatu objek adalah perasaan mendukung atau menarik (favorable) maupun perasaan tidak mendukung atau tidak memihak (unfavorable) pada objek tersebut.

Menurut Allport yang dikutip dalam Djaali dan Mulyono (2004:114), sikap adalah suatu kesiapan mental dan saraf yang tersusun melalui pengalaman dan memberikan pengaruh langsung kepada respond individu terhadap semua objek atau situasi yang berhubungan dengan objek itu. Menurut Secord dan Bacman (1964) dalam Azwar $(2016,5)$ sikap merupakan keteraturan pemikiran (kognisi), perasaan (afeksi), dan predisposisi tindakan (konasi).

Sikap merupakan keteraturan perasaan, pikiran, dan kecenderungan perilaku seseorang terhadap objek tertentu di lingkungannya (Secord \& Bacman, 1964). Sikap selalu digerakkan atas evaluasi pada sesuatu atau seseorang, sehingga dapat memengaruhi pembelajaran serta perfomansi siswa. Sikap siswa pada matematika memengaruhi cara mereka mengikuti pelajaran matematika (Aiken, 1974), sehingga menjadi faktor kunci bagi performansi matematika (Lipnevich, Mac Cann, Krumm, Burrus, \& Roberts, 2009; Nicolaidou \& Philippou, 2003).

Siswa umumnya memiliki sikap terhadap matematika yang positif ketika pertama masuk sekolah tetapi lama kelamaan sikap tersebut akan berkurang dan menjadi sikap negatif saat memasuki jenjang yang lebih tinggi (de Lourdes Mata, Monteiro, \& Peixoto, 2012; Nicolaidou \& Philippou, 2003). Sikap yang berkaitan dengan sekolah adalah sikap peserta didik terhadap mata pelajaran dan sikap peserta didik terhadap guru mata pelajaran, misalnya matematika.

Kaitan sikap dalam belajar Dimyanti (2006: 239) menyatakan bahwa sikap belajar merupakan kemampuan memberikan penilaian tentang sesuatu yang membawa diri sesuai dengan penilaian. Adanya penilaian tentang sesuatu mengakibatkan terjadinya sikap menerima, menolak, merasa senang dan tidak senang dalam melakukan aktivitas belajar. Menurut (Lambertus, Ambarsari, Faad, 2016: 106), sikap siswa dalam belajar dapat diartikan sebagai kecenderungan siswa dalam berperilaku tertentu tatkala dia mempelajari hal-hal yang bersifat akademik. Sikap belajar yang positif juga dapat disamakan dengan minat. Dengan mengacu kepada pengertian tentang sikap secara umum, maka sikap belajar dapat diartikan sebagai kecenderungan siswa untuk bereaksi terhadap pelajaran di sekolah.

Sikap juga dapat diartikan sebagai kecenderungan individu untuk merasa senang dan tidak senang terhadap suatu objek. Reaksi positif atau senang dan reaksi negatif atau tidak senang yang ditunjukkan oleh siswa di kelas dipengaruhi oleh berbagai faktor. (Hadis dan Nurhayati, 2008: 38) mengatakan faktor-faktor yang mempengaruhi siswa ialah kemampuan dan gaya mengajar guru di kelas, metode, pendekatan dan strategi pembelajaran yang dipengaruhi oleh guru, media pembelajaran, sikap dan perilaku guru, suara guru, lingkungan kelas, manajemen kelas dan berbagai faktor lain yang turut mempengaruhi sikap siswa. Jika semua faktor tersebut memberikan pengaruh positif kepada siswa, maka sikap yang terbentuk pada diri siswa ialah sikap belajar yang baik, yaitu siswa merasa senang dalam mengikuti proses pembelajaran yang dikelola oleh guru di kelas. Kemudian sebaliknya jika semua faktor tersebut memberikan pengaruh negatif kepada siswa, maka sikap siswa yang terbentuk pada diri siswa ialah sikap belajar yang tidak baik yaitu siswa merasa tidak senang dalam mengikuti pembelajaran yang dikelola guru di kelas. Perilaku yang diperhatikan siswa yang bersifat negatif atau tidak senang terhadap proses pembelajaran berupa sikap acuh tak acuh (apatis), siswa tidak aktif mengikuti pembelajaran, mengganggu teman se bangkunya, tidak mengerjakan atau menyelesaikan tugas-tugas yang diberikan kepadanya, keluar masuk kelas, dan berbagai bentuk perilaku menyimpang lainnya. Tingkah laku yang positif atau senang terhadap proses pembelajaran yang ditunjukkan siswa ialah siswa aktif, tekun, ulet, menyelesaikan tugastugas belajar dengan baik (tanggung jawab), disiplin dalam belajar, tidak keluar masuk kelas, 
menghormati guru dan teman sekelasnya, aktif bertanya dan menjawab pertanyaan guru, menunjukkan kerja sama yang baik dengan teman kelas dan melakukan tugas-tugas belajar secara berkelompok dan sebagainya. Sedangkan sikap belajar siswa terhadap mata pelajaran matematika dapat dilihat dari bagaimana siswa memahami tujuan dan isi mata pelajaran matematika, cara siswa dalam mempelajari mata pelajaran matematika.

Pada dasarnya sikap terhadap matematika adalah perasaan emosional positif atau negatif terhadap matematika (Zan \& Martino, dalam Akinsola dan Olowojaiye, 2008: 62). Menurut Hart (Akinsola dan Olowojaiye, 2008: 62) sikap individu terhadap matematika merupakan cara yang kompleks tentang emosi yang berhubungan dengan matematika, keyakinan matematika, meliputi sikap positif dan negative, dan bagaimana siswa bertingkah laku terhadap matematika. Hannula dalam Curtis (2006) mendefinisikan sikap sebagai sifat emosional terhadap matematika.

Sikap yang kurang apresiatif dan negatif terhadap mata pelajaran dapat menyebabkan kurangnya minat, motivasi, dan target dalam mengikuti mata pelajaran tersebut dan akan berdampak pada hasil yang diraih. Padahal menurut Hudoyo (1988:3) pelajaran matematika berkaitan dengan konsep-konsep abstrak yang pemahamannya membutuhkan daya nalar yang tinggi, ketekunan, keuletan, perhatian dan motivasi yang tinggi. Semua itu hanya bisa terwujud jika siswa memiliki sikap yang apresiatif dan positif terhadap mata pelajaran tersebut.

Tapia dan Marsh (Curtis, 2006), menyatakan bahwa ada lima faktor yang mempengaruhi sikap siswa terhadap matematika, yaitu:

1) Kepercayaan, yaitu keyakinan siswa atas kemampuannya dalam matematika;

2) Kekhawatiran, yaitu perasaan khawatir siswa akan matematika;

3) Nilai, yaitu keyakinan siswa akan kegunaan, relevansi, dan keberangan matematika dalam kehidupan pribadi siswa dan kehidupan profesional mereka di masa depan;

4) Kesenangan, yaitu perasaan nyaman siswa dalam belajar matematika dan terlibat dalam kelas matematika; Motivasi, yaitu keinginan dan minat siswa untuk belajar matematika.

Selain faktor sikap, motivasi juga berpengaruh terhadap keberhasilan belajar siswa. Motivasi merupakan suatu perubahan yang terdapat dalam diri seseorang untuk melakukan sesuatu guna mencapai tujuan. Tujuan yang hendak dicapai siswa ini merupakan pendorong atau penyemangat bagi siswa untuk lebih giat belajar. Dengan motivasi ini, siswa menjadi tekun dalam proses belajar mengajar, dan dengan motivasi pula kualitas hasil belajar siswa dapat diwujudkan dengan baik. Siswa yang mempunyai motivasi kuat dan jelas akan tekun dalam proses belajar mengajar dan akan berhasil dalam belajarnya.

Pelajaran matematika yang Sampai saat ini masih menjadi sesuatu yang menakutkan bagi sebagian besar siswa. Matematika dianggap sebagai mata pelajaran yang kurang menarik, sukar dan membosankan sehingga pelajaran matematika menjadi kurang disenangi. Hal ini haruslah ada pemberian motivasi dan dorongan belajar matematika baik dari guru maupun dari dalam diri siswa itu sendiri agar para siswa berminat dan termotivasi untuk belajar pelajaran matematika, serta tidak lepas dari bimbingan belajar oleh orang tua.

Motivasi adalah keadaan dalam pribadi seseorang yang mendorong keinginan individu untuk melakukan kegiatan-kegiatan tertentu guna mencapai suatu tujuan (Risnawita dan Ghufron, 2010: 83). Motivasi belajar adalah suatu perubahan tenaga di dalam diri seseorang (pribadi) yang ditandai dengan timbulnya perasaan dan reaksi untuk mencapai tujuan (Frederick J. Mc Donal dalam Nashar, 2004:39). Menurut M. Dalyono (2009: 57) motivasi belajar adalah suatu daya penggerak atau dorongan yang dimiliki oleh manusia untuk melakukan suatu pekerjaan yaitu belajar.

Menurut (Hamzah, 2006: 23) motivasi belajar dapat timbul karena faktor intrinsik dan ekstrinsik. Faktor intrinsik yang mempengaruhi motivasi belajar yaitu "pertama, hasrat dan keinginan berhasil, kedua dorongan kebutuhan belajar, dan ketiga, harapan akan cita-cita". Faktor ekstrinsik yang mempengaruhi motivasi belajar meliputi "pertama adanya penghargaan, kedua, lingkungan belajar yang kondusif, dan ketiga, kegiatan belajar yang menarik". 
Sardiman A.M (2012: 83) mengemukakan ciri-ciri motivasi yang ada lama, tidak pernah berhenti sebelum selesai.

1) Ulet menghadapi kesulitan (tidak lekas putus asa) tidak memerlukan dorongan dari luar untuk berprestasi sebaik mungkin (tidak cepat puas dengan prestasi yang telah dicapainya).

2) Menunjukkan minat terhadap bermacammacam masalah.

3) Lebih senang bekerja mandiri.

4) Cepat bosan pada tugas yang rutin (hal-hal yang bersifat mekanis, berulang-ulang begitu saja, sehingga kurang efektif.

5) Dapat mempertahankan pendapatnya (kalau sudah yakin akan sesuatu).

6) Tidak mudah melepaskan hal yang diyakini itu.

7) Senang mencari dan memecahkan masalah soal-soal.

Motivasi berkaitan dengan suatu tujuan. Sehubungan dengan hal tersebut (Sardiman, 2012: 85) menyebutkan ada tiga fungsi motivasi, yaitu:

1) Mendorong manusia untuk berbuat, yang akan menjadi penggerak dari setiap kegiatan yang akan dikerjakan.

2) Menentukan arah perbuatan, yaitu ke arah yang hendak dicapai.

3) Menyeleksi perbuatan, yaitu menentukan perbuatan- perbuatan apa yang harus dikerjakan yang sesuai untuk mencapai tujuan, dengan mengesampingkan perbuatanperbuatan yang tidak bermanfaat bagi tujuan tersebut.

Menurut Hamalik (2016: 161) ada tiga fungsi motivasi, yaitu sebagai berikut: a) Mendorong timbulnya kelakuan atau sesuatu perbuatan. Tanpa motivasi maka tidak akan timbul suatu perbuatan seperti belajar, b) Motivasi berfungsi sebagai pengarah. Artinya menggerakkan perubahan ke arah pencapaian tujuan yang diinginkan, dan c) Motivasi berfungsi sebagai penggerak. Motivasi sebagai mesin, besar kecilnya motivasi akan menentukan cepat atau lambatnya suatu pekerjaan atau perbuatan.

Menurut Anni (2006: 186-187) ada beberapa strategi motivasi belajar antara lain sebagai berikut:

1. Membangkitkan minat belajar

Pengaitan pembelajaran dengan minat siswa adalah sangat penting dan karena itu tunjukkanlah bahwa pengetahuan yang dipelajari itu sangat bermanfaat bagi mereka. Cara lain yang dapat dilakukan adalah memberikan pilihan kepada siswa tentang materi pembelajaran yang akan dipelajari dan cara-cara mempelajarinya.

2. Mendorong rasa ingin tahu

Guru yang terampil akan mampu menggunakan cara untuk membangkitkan dan memelihara rasa ingin tahu siswa di dalam kegiatan pembelajaran. Metode pembelajaran studi kasus, dikoveri, inkuiri, diskusi, curah pendapat, dan sejenisnya merupakan beberapa yang dapat digunakan untuk membangkitkan hasrat ingin tahu siswa.

3. Menggunakan variasi metode penyajian yang menarik

Motivasi untuk belajar dapat ditingkatkan melalui penggunaan materi pembelajaran yang menarik dan juga penggunaan variasi metode penyajian.

4. Membantu siswa dalam merumuskan tujuan belajar

Prinsip yang mendasar dari motivasi adalah anak akan belajar keras untuk mencapai tujuan apabila tujuan itu dirumuskan atau ditetapkan oleh dirinya sendiri dan bukan dirumuskan atau ditetapkan oleh orang lain.

Menurut Alderfer (Nashar 2004: 42) motivasi belajar adalah kecenderungan siswa dalam melakukan kegiatan belajar yang didorong oleh hasrat untuk mencapai prestasi atau hasil belajar sebaik mungkin. Motivasi untuk belajar merupakan hal yang paling penting agar siswa dapat sukses mempelajari suatu ilmu pengetahuan khususnya matematika, karena dengan motivasi inilah siswa menjadi tekun dalam proses belajar dan kualitas hasil belajar siswa juga dapat diwujudkan. Motivasi dapat mendorong atau menentukan tingkat berhasil atau gagalnya siswa dalam belajar. Belajar tanpa adanya motivasi sulit untuk mencapai keberhasilan secara optimal. Dalam proses pembelajaran matematika motivasi bukan saja mengerakkan tingkah laku, tetapi juga mengarahkan memperkuat tingkah laku siswa agar memiliki motivasi dalam belajar, menunjukkan minat, kegairahan dan ketekunan yang tinggi dalam belajar tanpa tergantung banyak kepada guru maupun orang lain. Motivasi yang kurang baik akan berdampak nyata pada rendahnya hasil belajar siswa. 
Berdasarkan hasil observasi di SMP Negeri 12 Kendari diperoleh informasi dari guru matematika masih ada sikap siswa kurang positif terhadap pelajaran matematika, yaitu pada saat jam pelajaran matematika siswa sering meninggalkan kelas, siswa belajar matematika saat ulangan saja, siswa mempelajari mata pelajaran lain pada saat pelajaran matematika, siswa mengerjakan pekerjaan rumah (PR) di sekolah dan pada saat proses belajar mengajar yang bertanya hanyalah siswa yang pintar saja. Motivasi siswa untuk belajar juga masih kurang yaitu, pada saat mengikuti pelajaran terdapat siswa yang kurang memperhatikan guru, baik pada saat guru menjelaskan materi pelajaran ataupun pada saat guru memberikan latihan atau contoh soal. Selain itu, kurang aktifnya siswa di kelas pada saat proses belajar mengajar berlangsung yang ditunjukkan dengan kurangnya siswa bertanya. Selain itu, diketahui bahwa saat diberikan tugas, masih terdapat siswa yang tidak mengerjakan tugas. Menurut Suherman $(2003$; 197) bahwa siswa mempunyai masalah dalam motivasi belajar matematikanya diantaranya cenderung untuk menghindari pelajaran matematika, siswa gagal dalam melakukan tugas-tugas matematika dan siswa menolak untuk mengikuti kegiatan-kegiatan matematika, baik di dalam maupun di luar kelas.

Hasil belajar matematika siswa juga masih belum memuaskan, dalam hal ini belum sepenuhnya mencapai standar kriteria ketuntasan minimal (KKM) yang telah ditetapkan di sekolah yaitu 70. Hasil belajar tersebut jelas terlihat dari hasil ulangan tengah semester siswa yaitu sekitar $63 \%$ sudah mencapai standar kriteria ketuntasan minimal, tetapi masih ada pula $37 \%$ yang belum mencapai standar kriteria ketuntasan minimal. Bisa dikatakan tuntas dalam mata pelajaran matematika apabila sekurangkurangnya $80 \%$ siswa dalam kelas memperoleh nilai lebih dari atau sama dengan 70. Masalah ini tentunya merupakan tantangan semua elemen yang bertanggung jawab atas terciptanya peningkatan hasil belajar matematika, khususnya bagi guru untuk mengetahui faktor-faktor penyebab rendahnya hasil belajar matematika siswa.

Kenyataan ini mendorong keinginan penulis untuk mengungkapkan lebih lanjut tentang sikap dan motivasi kaitannya dengan hasil belajar matematika siswa dengan judul "Pengaruh Sikap dan Motivasi Siswa
Terhadap Hasil Belajar Matematika Siswa Kelas VII SMP Negeri 12 Kendari Tahun Pelajaran 2017/2018".

\section{Metode}

Jenis penelitian yang digunakan adalah ex post facto. Penelitian ex post facto merupakan susunan penelitian yang dilakukan untuk meneliti peristiwa yang telah terjadi dan kemudian melihat ke belakang untuk mengenai faktor-faktor yang dapat menimbulkan kejadian tersebut (Sujarweni, 2014: 23). Dengan demikian, penelitian ex post facto adalah penelitian untuk menjelaskan atau menemukan bagaimana variabel-variabel dalam penelitian saling berhubungan atau berpengaruh. Dalam penelitian ini, yang menjadi populasi adalah siswa kelas VII SMP Negeri 12 Kendari semester genap tahun ajaran 2017/2018 yang terdiri dari 10 kelas paralel dengan jumlah siswa 301 orang. Berdasarkan populasi tersebut diambil sampel $47 \%$ atau 142 orang. 142 orang sampel diambil dari 10 kelas. Dengan demikian masing kelas diambil secara acak sebanyak $47 \%$ dari jumlah keseluruhan siswa di tiap-tiap kelas dengan teknik proporsional random sampling.

Gambaran hubungan antara tiga variabel dalam penelitian ini dapat dilihat dalam desain penelitian sebagai berikut:

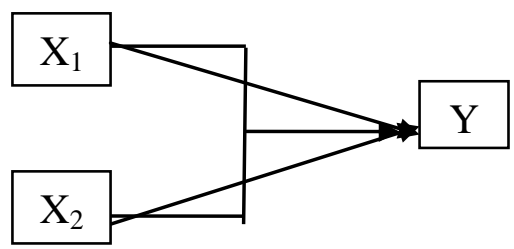

Keterangan : $\mathrm{X}_{1}=$ Sikap Siswa Pada Pelajaran Matematika, $X_{2}=$ Motivasi Siswa Pada Pelajaran Matematika dan $\mathrm{Y}=$ Hasil Belajar Matematika.

Teknik pengumpulan data yang digunakan pada penelitian ini adalah: 1) Angket yang digunakan untuk mengetahui skala sikap siswa pada pelajaran matematika dan motivasi siswa pada pelajaran matematika, 2) Nilai ujian akhir semester genap tahun ajaran 2017/2018 yang didapatkan dari guru mata pelajaran matematika

Teknik analisis data yang dilakukan pada penelitian ini diawali dengan menganalisis validitas dan reliabilitas hasil uji coba angket yang dilakukan pada 36 responden yang berasal dari SMP Negeri 09 Kendari. Selanjutnya analisis data dilakukan secara deskriptif dan 
inferensial. Analisis statistik deskriptif diperlukan untuk menggambarkan karakteristik distribusi masing-masing data variabel (sikap siswa pada pelajaran matematika, motivasi siswa pada pelajaran matematika dan hasil belajar matematika) berupa mean, modus, nilai minimum, nilai maksimum dan standar deviasi. Analisis inferensial dalam penelitian ini dilakukan dengan menggunakan uji regresi linear sederhana. dan uji regresi linear berganda yang sebelum melakukan analisis inferensial terlebih dahulu dilakukan uji prasyarat analisis.

Instrumen yang digunakan untuk memperoleh data variabel bebas (sikap sikap siswa pada pelajaran matematika siswa dan motivasi siswa pada pelajaran matematika) dalam penelitian ini adalah angket, dan angket tersebut menggunakan skala liker, dimana tiap item terdiri dari lima (5) alternatif jawaban dengan kriteria sebagai berikut:

Tabel 1

Alternatif Jawaban Menurut Skala Likert

\begin{tabular}{|l|c|c|}
\hline \multirow{2}{*}{\multicolumn{1}{|c|}{ Alternatif Jawaban }} & \multicolumn{2}{c|}{ Skor Untuk Pernyataan } \\
\cline { 2 - 3 } & Positif & Negatif \\
\hline Sangat Setuju (SS)/Selalu (SL) & 5 & 1 \\
\hline Setuju (S)/Sering (SR) & 4 & 2 \\
\hline Kurang Setuju (KS)/Kadang-Kadang (KD) & 3 & 3 \\
\hline Tidak Setuju (TS)/Jarang (JR) & 2 & 4 \\
\hline Sangat Tidak Setuju (STS)/Tidak Pernah (TP) & 1 & 5 \\
\hline
\end{tabular}

Sumber: Siregar (2013: 75)

Hasil

\section{Analisis Deskriptif Sikap Siswa Pada} Pelajaran Matematika $\left(\mathbf{X}_{1}\right)$

Berdasarkan hasil analisis data sikap siswa pada pelajaran matematika yang diperoleh melalui angket, distribusi nilai sikap siswa pada pelajaran matematika siswa Kelas VII SMP Negeri 12 Kendari Tahun Pelajaran 2017/2018 berkisar antara 69 (nilai minimum) sampai dengan 117 (nilai maksimum). Rata-rata nilai sikap siswa pada pelajaran matematika adalah 91,99, standar deviasi 9,30.

Tabel 2

Distribusi Sikap Siswa Pada Pelajaran Matematika

\begin{tabular}{|c|c|c|c|c|}
\hline No & Interval & Frekuensi & Presentasi (\%) & Kriteria \\
\hline 1 & $\mathrm{X} \geq 105,93$ & 12 & 8,45 & Sangat Baik \\
\hline 2 & $96,63<\mathrm{X} \leq 105,93$ & 29 & 20,42 & Baik \\
\hline 3 & $87,63<\mathrm{Y} \leq 96,63$ & 61 & 42,96 & Sedang \\
\hline 4 & $78,04<\mathrm{Y} \leq 87,34$ & 29 & 20,42 & Rendah \\
\hline 5 & $\mathrm{Y} \leq 78,04$ & 11 & 7,75 & Sangat Rendah \\
\hline
\end{tabular}

Analisis Deskriptif Motivasi Siswa Pada Pelajaran Matematika $\left(\mathbf{X}_{2}\right)$

Berdasarkan hasil analisis data motivasi siswa pada pelajaran matematika yang diperoleh melalui angket, distribusi nilai motivasi siswa pada pelajaran matematika siswa Kelas VII SMP
Negeri 12 Kendari Tahun Pelajaran 2017/2018 berkisar antara 69 (nilai minimum) sampai dengan 125 (nilai maksimum). Rata-rata nilai sikap siswa pada pelajaran matematika adalah 94,45, standar deviasi 11,38

Tabel 3

Distribusi Motivasi Siswa Pada Pelajaran Matematika

\begin{tabular}{|c|c|c|c|c|}
\hline No & Interval & Frekuensi & Persentase (\%) & Kriteria \\
\hline 1 & $\mathrm{Y} \geq 111,52$ & 8 & 5,63 & Sangat Baik \\
\hline 2 & $100,14<\mathrm{Y} \leq 111,52$ & 34 & 23,94 & Baik \\
\hline 3 & $88,76<\mathrm{Y} \leq 100,14$ & 54 & 38,03 & Sedang \\
\hline 4 & $77,38<\mathrm{Y} \leq 88,76$ & 32 & 22,54 & Rendah \\
\hline 5 & $\mathrm{Y} \leq 77,38$ & 14 & 9,86 & Sangat Rendah \\
\hline
\end{tabular}


Analisis Deskriptif Hasil Belajar Matematika Siswa (Y)

Berdasarkan hasil analisis data hasil belajar matematika yang diperoleh dari hasil tes, distribusi hasil belajar matematika siswa Kelas VII SMP Negeri 12 Kendari Tahun Pelajaran
2017/2018 berkisar antara 45 (nilai minimum) sampai dengan 89 (nilai maksimum). Rata-rata nilai sikap siswa pada pelajaran matematika adalah 70,75, standar deviasi 8,45, dan skewness $-0,30$

Tabel 4

Distribusi Hasil Belajar Matematika

\begin{tabular}{|c|c|c|c|c|}
\hline No & Interval & Frekuensi & Persentase & Kriteria \\
\hline 1 & $85<\mathrm{Y} \leq 100$ & 5 & $3,52 \%$ & Sangat Baik \\
\hline 2 & $70<\mathrm{Y} \leq 100$ & 70 & $49,3 \%$ & Baik \\
\hline 3 & $55<\mathrm{Y} \leq 70$ & 60 & $42,25 \%$ & Cukup \\
\hline 4 & $\mathrm{Y} \leq 55$ & 7 & $4,93 \%$ & Kurang \\
\hline
\end{tabular}

\section{Analisis Inferensial}

Sebelum melakukan analisis inferensial, terlebih dahulu dilakukan pengujian normalitas data, uji multi kolinearitas, dan uji linearitas.

a. Uji normalitas

Uji normalitas data sikap siswa pada pelajaran matematika $\left(\mathrm{X}_{1}\right)$, motivasi siswa pada pada pelajaran matematika $\left(\mathrm{X}_{2}\right)$ dan hasil belajar matematika (Y) pada penelitian ini menggunakan Kolmogrov-Smirniv dengan bantuan SPSS (semi manual) dan diperoleh tabel berikut ini.

Tabel 5

One-sample kolmogorov-smirnow test

\begin{tabular}{|l|l|r|r|r|}
\hline \multicolumn{2}{|c|}{} & \multicolumn{1}{|c|}{ Sikap } & Motivasi & \multicolumn{1}{c|}{$\mathrm{Y}$} \\
\hline $\mathrm{N}$ & 142 & 142 & 142 \\
\hline $\begin{array}{l}\text { Normal } \\
\text { Parameters }\end{array}$ & Mean & 91.9930 & 94.4507 & 70.7535 \\
\cline { 2 - 6 } & Std. Deviation & 9.30149 & $1.13772 \mathrm{E} 1$ & 8.45278 \\
\hline $\begin{array}{l}\text { Most Extreme } \\
\text { Differences }\end{array}$ & Absolute & .045 & .089 & .083 \\
\cline { 2 - 6 } & Positive & .038 & .039 & .083 \\
\cline { 2 - 6 } & Negative & -.045 & -.089 & -.079 \\
\hline Kolmogorov-Smirnov Z & .538 & 1.065 & .988 \\
\hline \multicolumn{2}{|l|}{ Asymp. Sig. (2-tailed) } & .935 & .207 & .283 \\
\hline
\end{tabular}

a. Test distribution is Normal.

Berdasarkan tabel 5. Diperoleh niali Asymp. Sig (2-tailed) $\left(\mathrm{X}_{1}\right)=0,935$ Asymp. Sig (2-tailed) $\left(\mathrm{X}_{2}\right)=0,207$ dan Asymp. Sig (2-tailed) dari masing-masing variabel $>$ Signifikan $(\alpha)=$ 0.05 , artinya data sampel masing-masing variabel berasal dari distribusi normal.

$(Y)=0,283$. karena nilai Asymp. Sig (2-tailed)

b. Uji Linearitas

Tabel 6

Uji Linearitas Variabel Penelitian

\begin{tabular}{|l|l|l|r|r|r|r|r|}
\hline \multicolumn{7}{|c|}{ ANOVA Table } \\
\hline
\end{tabular}


Jurnal Pendidikan Matematika Volume 6 No.1 Januari 2018

\begin{tabular}{|l|l|l|r|r|r|r|r|}
\hline $\begin{array}{l}\text { Y* } \\
\text { Motiva } \\
\text { si } \\
\text { Siswa }\end{array}$ & Between & Groups & 6993.584 & 44 & 158.945 & 5.004 & .000 \\
\cline { 2 - 7 } & & Linearity & 5808.015 & 1 & 5808.015 & 182.868 & .000 \\
\cline { 2 - 7 } & Deviation from Linearity & 1185.569 & 43 & 27.571 & .868 & .693 \\
\cline { 2 - 8 } & Within Groups & 3080.789 & 97 & 31.761 & & \\
\cline { 2 - 8 } & Total & 10074.373 & 141 & & & \\
\hline
\end{tabular}

Dari output di atas dapat diketahui bahwa linearty motivasi siswa terhadap hasil belajar nilai signifikan pada linearity sikap siswa matematika $0,000<0,05$ maka dapat terhadap hasil belajar matematika $0,000<0,05$ disimpulkan bahwa antara variabel motivasi maka dapat bahwa antara variabel sikap dan siswa dan hasil belajar matematika terdapat hasil belajar matematika terhadap hubungan hubungan yang linear. yang linear. Demikian pula nilai signifikan pada c. Uji Multikolinearitas

Berdasarkan hasil analisis dengan SPSS, diperoleh data sebagai berikut.

Tabel 7

Coefficients $^{\mathrm{a}}$

\begin{tabular}{|l|l|r|r|}
\hline \multicolumn{2}{|l|}{ Model } & \multicolumn{2}{c|}{ Collinearity Statistics } \\
\cline { 2 - 4 } 1 & Tolerance & \multicolumn{1}{c|}{ VIF } \\
\hline \multirow{3}{*}{1} & $($ Constant) & & \\
\cline { 2 - 4 } & Sikap Siswa & .559 & 1.790 \\
\cline { 2 - 4 } & Motivasi Siswa & .559 & 1.790 \\
\hline
\end{tabular}

a. Dependent Variable: Hasil belajar Siswa

Berdasarkan tabel di atas dapat dijelaskan bahwa data sikap siswa pada pelajaran matematika $\left(\mathrm{X}_{1}\right)$ dan motivasi siswa $\left(\mathrm{X}_{2}\right)$ tidak terjadi multikolinearitas. Hal ini dilihat dari Tabel 8. Coefficient correlations diperoleh 0,664 dan pada Tabel 7. coefficients $(\alpha)$ diperoleh Variance Inflation Factor (VIF) $=$ $1,790<5=$ Variance Inflation Factor (VIF) yang diperoleh dari $0,05 \times 100=\alpha \times 100$, untuk $\alpha=0,05$.

koefisien korelasi antara $\left(\mathrm{X}_{1}\right)$ dan $\left(\mathrm{X}_{2}\right)$ sebesar -

Tabel. 8

Cefficient Correlations $(\alpha)$

\begin{tabular}{|c|c|c|c|c|}
\hline \multicolumn{3}{|c|}{ Model } & motivasi & Sikap \\
\hline \multirow[t]{4}{*}{1} & \multirow[t]{2}{*}{ Correlations } & motivasi & 1.000 & -.664 \\
\hline & & Sikap & -.664 & 1.000 \\
\hline & \multirow[t]{2}{*}{ Covariances } & motivasi & .001 & .000 \\
\hline & & Sikap & .000 & .001 \\
\hline
\end{tabular}

a. Dependent Variable: hasil belajar

\section{1) Pengujian Hipotesis I}

Tabel 9

Koefisien Persamaan Regresi Sederhana Sikap Siswa Pada Pelajaran Matematika Terhadap Hasil Belajar Matematika. Coefficients $^{\mathrm{a}}$

\begin{tabular}{|c|c|c|c|c|c|c|}
\hline \multirow{2}{*}{\multicolumn{2}{|c|}{ Model }} & \multicolumn{2}{|c|}{$\begin{array}{l}\text { Unstandardized } \\
\text { Coefficients }\end{array}$} & \multirow{2}{*}{\begin{tabular}{|c|}
$\begin{array}{c}\text { Standardized } \\
\text { Coefficients }\end{array}$ \\
Beta \\
\end{tabular}} & \multirow[b]{2}{*}{$\mathrm{t}$} & \multirow[b]{2}{*}{ Sig. } \\
\hline & & B & Std. Error & & & \\
\hline \multirow[t]{2}{*}{1} & (Constant) & -6.819 & 2.647 & & -2.576 & .011 \\
\hline & Sikap Siswa $\left(\mathrm{X}_{1}\right)$ & .843 & .029 & .928 & 29.451 & .000 \\
\hline
\end{tabular}

a. Dependent Variable: Hasil Belajar 
Berdasarkan hasil analisis tentang penentuan persamaan regresi linear sederhana dari data sikap siswa pada pelajaran matematika dan hasil belajar matematika diperoleh nilai $\alpha=$ 6,819 dan $\mathrm{b}=0,843$ sehingga persamaan taksiran regresi linear sederhana yaitu $\hat{\mathrm{Y}}=$ $6,819+0,843 \mathrm{X}_{1}$ dan nilai koefisien determinasi $\mathrm{R}^{2}=0,861$ atau sama dengan $86,1 \%$.
Berdasarkan hasil analisis diperoleh nilai $\mathrm{T}_{\text {hitung }}(29,451)$ sedangkan nilai $\mathrm{T}_{\text {tabel }}(0,025 ; 140)$ sebesar 1,97705. Jadi nilai $\mathrm{T}_{\text {hitung }}>\mathrm{T}_{\text {tabel }}$, dengan demikian sikap siswa pada pelajaran matematika mempunyai pengaruh yang signifikan terhadap hasil belajar matematika siswa.

\section{2) Pengujian Hipotesis II}

\section{Tabel 10}

Koefisients Persamaan Regresi Sederhana Motivasi Siswa Pada Pelajaran Matematika Terhadap Hasil Belajar Matematika. Coefficients $^{\mathbf{a}}$

\begin{tabular}{|c|c|c|c|c|c|c|}
\hline \multicolumn{2}{|c|}{} & \multicolumn{2}{|c|}{$\begin{array}{c}\text { Unstandardized } \\
\text { Coefficients }\end{array}$} & $\begin{array}{c}\text { Standardized } \\
\text { Coefficients }\end{array}$ & & \\
\cline { 2 - 6 } & Model & B & Std. Error & Beta & \multirow{2}{*}{ Sig. } \\
\hline \multirow{2}{*}{1} & (Constant) & 17.472 & 3.887 & & 4.495 & .000 \\
\cline { 2 - 7 } & Motivasi Siswa (X2) & .564 & .041 & .759 & 13.805 & .000 \\
\hline
\end{tabular}

a. Dependent Variable: Hasil Belajar

Berdasarkan hasil analisis tentang penentuan persamaan regresi linear sederhana dari data motivasi siswa pada pelajaran matematika dan hasil belajar matematika diperoleh nilai $\alpha=17,472$ dan $b=0,564$ sehingga persamaan taksiran regresi linear sederhana yaitu $\hat{\mathrm{Y}}=17,472+0,564 \mathrm{X}_{1}$ dan nilai koefisien determinasi $\mathrm{R}^{2}=0,577$ atau sama dengan $57,7 \%$.

\section{3) Pengujian Hipotesis III}

Tabel 11

Koefisien Persamaan Regresi Berganda

\begin{tabular}{|c|c|c|c|c|c|}
\hline \multicolumn{6}{|c|}{ Coefficients $^{\mathbf{a}}$} \\
\hline \multirow[b]{2}{*}{ Model } & \multicolumn{2}{|c|}{$\begin{array}{l}\text { Unstandardized } \\
\text { Coefficients }\end{array}$} & \multirow{2}{*}{$\begin{array}{l}\text { Standardized } \\
\text { Coefficients } \\
\text { Beta }\end{array}$} & \multirow[b]{2}{*}{$\mathrm{t}$} & \multirow[b]{2}{*}{ Sig. } \\
\hline & $\mathrm{B}$ & Std. Error & & & \\
\hline \begin{tabular}{|l|l|}
1 (Constant) \\
\end{tabular} & -10.559 & 2.342 & & -4.508 & .000 \\
\hline Sikap Siswa $\left(\mathrm{X}_{1}\right)$ & .689 & .033 & .758 & 20.867 & .000 \\
\hline Motivasi Siswa $\left(\mathrm{X}_{2}\right)$ & .190 & .027 & .256 & 7.037 & .000 \\
\hline
\end{tabular}

a. Dependent Variable: Hasil Belajar (Y)

Berdasarkan hasil analisis tentang penentuan persamaan regresi linear sederhana dari data sikap siswa pada pelajaran matematika, motivasi siswa pada pelajaran matematika dan hasil belajar matematika diperoleh nilai $\alpha=$ -

$10,559, b_{1}=0,689$ dan $b_{2}=0,190$ sehingga persamaan taksiran regresi linear berganda yaitu $\hat{\mathrm{Y}}=-10,559+0,689 \mathrm{X}_{1}+0,190 \mathrm{X}_{2}$ dan nilai koefisien determinasi $\mathrm{R}^{2}=0,898$ atau sama dengan $89,8 \%$.

Tabel 12
$\mathrm{T}_{\text {hitung }}(13,805)$ sedangkan nilai $\mathrm{T}_{\text {tabel }}(0,025 ; 140)$ sebesar 1,97705 . Jadi nilai $\mathrm{T}_{\text {hitung }}>\mathrm{T}_{\text {tabel }}$, dengan demikian motivasi siswa pada pelajaran matematika mempunyai pengaruh yang signifikan terhadap hasil belajar matematika siswa.

Output ANOVA Regresi Berganda 
Jurnal Pendidikan Matematika Volume 6 No.1 Januari 2018

\begin{tabular}{|l|l|r|r|r|r|r|}
\hline \multicolumn{2}{|l|}{ Model } & $\begin{array}{c}\text { Sum of } \\
\text { Squares }\end{array}$ & Df & $\begin{array}{c}\text { Mean } \\
\text { Square }\end{array}$ & F & Sig. \\
\hline \multirow{4}{*}{1} & Regression & 9042.017 & 2 & 4521.008 & 608.724 & $.000^{\mathrm{a}}$ \\
\cline { 2 - 7 } & Residual & 1032.357 & 139 & 7.427 & & \\
\cline { 2 - 7 } & Total & 10074.373 & 141 & & & \\
\hline
\end{tabular}

a. Predictors: (Constant), Motivasi Siswa (X2), Sikap Siswa (X1)

b. Dependent Variable: Hasil Belajar (Y)

Berdasarkan hasil analisis diperoleh nilai $F_{\text {hitung }}$ untuk uji signifikan regresi berganda sebesar 608,724 sedangkan nilai $\mathrm{F}_{\text {tabel }}(\mathrm{dk}$ pembilang $=2$, dk penyebut $=139$ ) untuk taraf nyata $\alpha=0,05$. Sebesar 3,06 . Jadi nilai $F_{\text {hitung }}>$ $\mathrm{F}_{\text {tabel}}$, dengan demikian sikap siswa pada pelajaran matematika dan motivasi siswa pada pelajaran matematika mempunyai pengaruh yang signifikan terhadap hasil belajar matematika siswa.

\section{Pembahasan}

Berdasarkan hasil analisis deskriptif sikap siswa pada pelajaran matematika menunjukkan bahwa terdapat 12 atau $(8,45 \%)$ siswa yang memiliki sikap pada pelajaran matematika dalam kriteria tinggi, 29 atau $(20,42 \%)$ siswa yang memiliki sikap pada pelajaran matematika dalam kriteria tinggi, 61 atau $(42,96 \%)$ siswa yang memiliki sikap pada pelajaran matematika dalam kriteria sedang, 29 atau (20,42\%) siswa yang memiliki sikap siswa pada pelajaran matematika dalam kriteria rendah, dan 11 atau $(7,75 \%)$ siswa yang memiliki sikap pada pelajaran matematika dalam kriteria sangat rendah.

Berdasarkan hasil analisis deskriptif motivasi siswa pada pelajaran matematika menunjukkan bahwa terdapat 8 atau $(5,63 \%)$ siswa yang memiliki motivasi dalam kriteria sangat tinggi, 34 atau $(23,94 \%)$ siswa yang memiliki motivasi pada pelajaran matematika dalam kriteria tinggi, 54 atau $(38,03 \%)$ siswa yang memiliki motivasi pada pelajaran matematika dalam kriteria sedang, 32 atau $(22,54 \%)$ siswa yang memiliki motivasi pada pelajaran matematika dalam kriteria rendah, dan 14 atau $(9,86 \%)$ siswa yang memiliki motivasi pada pelajaran matematika dalam kriteria sangat rendah.

Berdasarkan hasil analisis deskriptif hasil belajar matematika siswa menunjukkan bahwa terdapat 5 atau $(3,52 \%)$ siswa yang memiliki hasil belajar matematika dalam kriteria sangat baik, 70 atau $(49,3 \%)$ siswa yang memiliki hasil belajar matematika dalam kriteria baik, 60 atau $(42,25 \%)$ siswa yang memiliki hasil belajar matematika dalam kriteria cukup, dan 7 atau $(4,93 \%)$ siswa yang memiliki hasil belajar matematika dalam kriteria kurang.

Berdasarkan hasil penelitian serta kenyataan yang ada di lapangan maka dapat diuraikan pembahasan sebagai berikut:

Berdasarkan hasil analisis regresi linear sederhana data sikap siswa pada pelajaran matematika terhadap hasil belajar matematika siswa kelas VII SMP Negeri 12 Kendari. Hasil analisis menunjukkan bahwa terdapat perbedaan hasil belajar matematika siswa ditinjau dari tingkat sikap siswa pada pelajaran matematika hal tersebut dapat dilihat pada nilai $\mathrm{t}_{\text {hitung }}=$ $29,451 \geq \mathrm{t}_{\text {tabel }}(0,025 ; 140)=1,97705$ maka $\mathrm{H}_{0}$ ditolak. Siswa dengan tingkat sikap siswa pada pelajaran matematika tinggi akan mempunyai hasil belajar matematika yang lebih baik dibandingkan dengan siswa yang mempunyai sikap pada pelajaran matematika rendah.

Persamaan regresi pengaruh sikap siswa pada pelajaran matematika yaitu: $\hat{Y}=-6,819+$ $0,843 \mathrm{X}_{1}$. Dari hasil persamaan regresi yang ada bahwa skor hasil belajar matematika siswa (Y) akan berubah sebesar 0,843 untuk perubahan setiap unit pada skor tingkat sikap siswa pada pelajaran matematika siswa.

Hal ini sesuai dengan pembahasan bahwa sikap siswa pada pelajaran matematika merupakan salah satu faktor yang dapat mempengaruhi usaha yang dilakukan seseorang. Sikap siswa yang positif pada pelajaran matematika akan menimbulkan usaha yang gigih, serius dan tidak mudah putus asa dalam menghadapi tantangan. Jika seorang siswa memiliki rasa ingin belajar, ia akan cepat dapat mengerti dan mengingatnya. Seorang siswa yang menaruh sikap positif terhadap mata pelajaran tertentu akan memusatkan perhatiannya lebih banyak dari pada mata pelajaran lainnya. Pemusatan perhatian yang intensif terhadap mata pelajaran tersebut memungkinkan siswa untuk belajar lebih giat dan akhirnya dapat mencapai 
hasil yang baik. Hal ini sejalan dengan penelitian pada siswa SMP Negeri 12 Kendari dimana nilai koefisien determinan $\mathrm{R}^{2}=0,861$ yang memberikan arti bahwa sikap siswa pada pelajaran matematika memiliki pengaruh yang cukup besar terhadap hasil belajar matematika. Sedangkan untuk menyatakan besarnya kontribusi (sumbangan) variabel sikap siswa pada pelajaran matematika $\left(\mathrm{X}_{1}\right)$ terhadap hasil belajar matematika $(\mathrm{Y})$ yaitu $\mathrm{R}^{2} \times 100 \%=$ $86,1 \%$, hal ini memberikan arti bahwa sikap siswa memiliki pengaruh yang besar terhadap hasil belajar matematika. Hal ini sangat sesuai dengan tanggapan guru pada saat observasi awal, menyatakan bahwa rendahnya hasil belajar siswa disebabkan karena adanya sikap negatif siswa untuk belajar matematika. Secara teori, sikap yang kurang apresiatif dan negatif terhadap mata pelajaran dapat menyebabkan kurangnya minat, motivasi dan target dalam mengikuti mata pelajaran tersebut dan akan berdampak pada hasil yang diraih.

Berdasarkan hasil analisis regresi linear sederhana data motivasi siswa pada pelajaran matematika terhadap hasil belajar matematika siswa kelas VII SMP Negeri 12 Kendari. Hasil analisis menunjukkan bahwa terdapat perbedaan hasil belajar matematika siswa ditinjau dari tingkat motivasi siswa. Hal ini dapat dilihat pada nilai $\mathrm{t}_{\text {hitung }}=13,805 \geq \mathrm{t}_{\text {tabel }(0,025 ; 140)}=1,97705$ maka $\mathrm{H}_{0}$ di tolak.

Hal tersebut menunjukkan bahwa hipotesis yang ditunjukkan dalam penelitian ini diterima. Dari data yang didapat oleh peneliti di lapangan menunjukkan bahwa siswa yang mempunyai tingkat motivasi yang tinggi mendukung nilai hasil belajar matematikanya.

Persamaan regresi pengaruh motivasi siswa terhadap hasil belajar matematika $\hat{Y}=$ $17,472+0,564 \mathrm{X}_{2}$. Dari hasil persamaan regresi yang ada bahwa skor hasil belajar matematika siswa (Y) akan berubah sebesar 0,564 untuk perubahan setiap unit pada skor tingkat motivasi siswa.

Seperti halnya sikap siswa pada pelajaran matematika, secara teoritis motivasi siswa juga merupakan salah satu faktor yang juga mempengaruhi keberhasilan belajar. Apabila seorang siswa berpedoman pada dimensidimensi motivasi yang positif maka akan menimbulkan hasil belajar yang sangat baik untuk siswa itu. Motivasi siswa yang positif akan menimbulkan perasaan yang senang dan semangat dalam belajar. Seorang siswa yang mempunyai motivasi positif akan memperlihatkan adanya minat, kegairahan, ketekunan yang tinggi dalam belajar, kepatuhan dalam dirinya serta selalu siap untuk belajar, sehingga siswa yang memiliki motivasi positif yang tinggi sangat memungkinkan memperoleh hasil belajar yang lebih baik. Berdasarkan hasil penelitian pada siswa SMP Negeri 12 Kendari dimana nilai coefisien determinasi $\mathrm{R}^{2}=0,564$ sedangkan untuk menyatakan besarnya kontribusi (sumbangan) variabel motivasi siswa $\left(\mathrm{X}_{2}\right)$ terhadap hasil belajar matematika (Y) yaitu $\mathrm{R}^{2} \times 100 \%=56,4 \%$, sedangkan sisanya $43,6 \%$ adalah merupakan kontribusi variabel-variabel lain yang

Berdasarkan hasil analisis regresi linear sederhana data sikap siswa pada pelajaran matematika dan motivasi siswa pada pelajaran matematika secara bersama-sama terhadap hasil belajar matematika siswa kelas VII SMP Negeri 12 Kendari. Dari hasil analisis data diperoleh persamaan regresi nya $\hat{Y}=-10,559+0,689 X_{1}+$ $0,190 \mathrm{X}_{2}$ dari persamaan tersebut dapat diartikan bahwa rata-rata skor hasil belajar matematika siswa (Y) akan mengalami perubahan sebesar 0,689 untuk setiap unit perubahan yang terjadi pada skor sikap siswa pada pelajaran matematika $\left(\mathrm{X}_{1}\right)$ dan juga diperkirakan akan mengalami perubahan nilai sebesar 0,190 untuk setiap unit yang terjadi pada skor tes motivasi siswa $\left(\mathrm{X}_{2}\right)$.

Hasil uji signifikansi dengan menggunakan SPSS diperoleh nilai $\mathrm{F}_{\text {hitung }}=$ $608,724 \geq \mathrm{F}_{\text {tabel }}(2,140)=3,06$ sehingga dapat disimpulkan bahwa persamaan regresi di atas merupakan persamaan regresi yang signifikan yaitu sudah dapat digunakan sebagai dasar pembuatan ramalan pada besarnya variabel $\mathrm{Y}$ (hasil belajar matematika siswa) berdasarkan besarnya variabel $X_{1}$ (sikap siswa pada pelajaran matematika) dan $X_{2}$ (motivasi siswa). Hal ini berarti bahwa ada pengaruh yang signifikan antara sikap dan motivasi siswa pada pelajaran matematika terhadap hasil belajar matematika siswa kelas VII SMP Negeri 12 Kendari.

Adapun besarnya pengaruh sikap dan motivasi siswa pada pelajaran matematika terhadap hasil belajar matematika siswa dengan melihat nilai kontribusi korelasi berganda yaitu $\mathrm{KP}=89,8 \%$ maksud dari angka tersebut menyatakan bahwa pengaruh sikap dan motivasi siswa pada pelajaran matematika terhadap hasil belajar matematika siswa secara bersama-sama 
adalah $89,8 \%$ dan $10,2 \%$ dipengaruhi oleh variabel lain.

\section{Simpulan dan Saran}

\section{Simpulan}

Berdasarkan hasil analisis data dan pembahasan diperoleh beberapa kesimpulan sebagai berikut:

1. Sikap siswa pada pelajaran matematika mempunyai pengaruh yang positif dan signifikan terhadap hasil belajar matematika siswa kelas VII SMP Negeri 12 Kendari Tahun Ajaran 2017/2018 pada semester genap. Hal tersebut dapat dilihat pada nilai $\mathrm{t}_{\text {hitung }}=29,451 \geq \mathrm{t}_{\text {tabel }(0,025 ; 140)}=1,97705$ yang berarti bahwa tingkat sikap siswa pada pelajaran matematika mempengaruhi hasil belajar matematika siswa. Hal tersebut dapat pula dilihat dari hasil persamaan regresi $\hat{Y}=$ $6,819+0,843 \mathrm{X}_{1}$ adapun sikap siswa pada pelajaran matematika memberikan pengaruh terhadap hasil belajar matematika sebesar $86,1 \%$.

2. Motivasi mempunyai pengaruh yang positif dan signifikan terhadap hasil belajar matematika siswa kelas VII SMP Negeri 12 Kendari Tahun Ajaran 2017/2018 pada semester genap. Hal tersebut dapat dilihat pada nilai $\mathrm{t}_{\text {hitung }}=13,805 \geq \mathrm{t}_{\text {tabel }}(0,025 ; 140)=$ 1,97705 yang berarti bahwa motivasi siswa mempengaruhi nilai hasil belajar matematika siswa. Hal tersebut dapat pula dilihat dari hasil persamaan regresi $\hat{Y}=17,472+$ $0,564 \mathrm{X}_{1}$ adapun motivasi memberikan pengaruh terhadap hasil belajar matematika siswa sebesar $57,7 \%$.

3. Sikap dan motivasi siswa pada pelajaran matematika secara bersama-sama mempunyai pengaruh yang positif dan signifikan terhadap hasil belajar matematika siswa kelas VII SMP Negeri 12 Kendari Tahun Ajaran 2017/2018 pada semester genap. Hal tersebut dapat dilihat pada nilai $\mathrm{F}_{\text {hitung }}=608,724 \geq$ $\mathrm{F}_{\text {tabel }}=3,06$ yang berarti bahwa tingkat sikap dan motivasi siswa pada pelajaran matematika secara bersama-sama memberikan perbedaan hasil yang signifikan terhadap nilai hasil belajar matematika siswa. Hal tersebut dapat dilihat dari hasil persamaan regresi $\hat{Y}=-10,559+0,689 \mathrm{X}_{1}+$ $0,190 \mathrm{X}_{2}$ adapun sikap dan motivasi siswa pada pelajaran matematika secara bersama- sama memberikan pengaruh terhadap hasil belajar matematika siswa sebesar $89,8 \%$.

\section{Saran}

Berdasarkan hasil penelitian ini, maka peneliti mengemukakan saran-saran sebagai berikut:

1. Dari hasil penelitian, ada pengaruh antara sikap dan motivasi terhadap hasil belajar. Bagi guru hendaknya harus bisa membangkitkan sikap dan motivasi siswa. Seorang guru dalam menyampaikan pelajaran harus mampu membuat siswa senang dalam belajar. Dengan adanya sikap dan motivasi yang timbul maka besarlah usaha yang dilakukan untuk mempelajari pelajaran tersebut, dan diharapkan siswa memperoleh hasil belajar yang baik.

2. Dari penelitian selain sikap dan motivasi yang mempengaruhi hasil belajar siswa ternyata ada faktor-faktor lain yang pengaruhnya besar terhadap hasil belajar matematika. Karena itu perlu dikembangkan penelitian berikutnya untuk memecahkan faktor-faktor lain yang sangat mempengaruhi hasil belajar matematika guna meningkatkan kualitas belajar mengajar.

\section{Daftar Pustaka}

Aiken, L.R. (1974). Two Scales Of Attitude Toward Mathematics. Journal Fof Reseach Mathematics Educations. 5(2), 67-71.

Anni, Chatarina Tri. (2006). Psikologi Belajar. Semarang: UPT UNES Perss.

Azwar, S. 2016. Sikap Manusia, Teori dan Pengukuranya. Jogjakarta: Pustaka Pelajar Jogja Offset.

B. Uno, Hamzah. (2006). Orientasi Baru dalam Psikologi Pembelajaran. Jakarta: PT. Bumi Aksara.

Curtis, Karena M. (2006). Improving Student Attitudes: A Study of A Mathematics Curriculum Innovation. http://krex.kstate.edu/dspace/bitstream/2097/151/1/ Karena Curtis2006.pdf. Diakses 06 Oktober 2018.

Dalyono, M. (2009). Psikologi Pendidikan. Jakarta: Renika Cipta. 
De Lourdes Mata, M., Monteiro, V., \& Piexoto, F. (2012). Attitudes Towards Mathematics: Effects Of Individual, Motivation, and Social Support Factors. Hindawi Publishing Corporation, Child Developmen Reseach, 2012, 1-10.

Djaali dan Mulyono. ( 2004). Pengukuran Dalam Bidang Pendidikan. Jakarta: PPs Universitas Negeri Jakarta.

Hadis, Abdul \& Nurhayati, B. (2008). Psikologi dalam Pendidikan. Bandung: Alfabeta.

Hallen. (2005). Bimbingan dan Konseling. Jakarta: Quantum Teaching.

Hamalik, Oemar. (2016). Prosedur Belajar Mengajar. Jakarta: Bumi Aksara.

Hudoyo (1988), Pengembangan Kurikulum Matematika dan Pelaksanaannya di Depan Kelas. Surabaya: Usaha Nasional.

Jihat, A dan Haris, A. (2008). Evaluasi Pembelajaran. Yogyakarta: Multi Pressindo.

Mulyasa, H.E. (2007). Menjadi Guru Profesional. Bandung: Remaja Rosdakarya.

Nashar, Drs. (2004). Peranan Motivasi dan Kemampuan Awal Dalam Kegiatan Pembelajaran. Jakarta: Delia Press.

Nicolaidou, M., \& Philippou, G. (2003). Attitudes Towards Mathematics, Self Efficacy and Achievement in Prolem Solving. European Reseach in Mathematics III.

Sardiman, A.M. (2012). Intraksi dan Motivasi Belajar Mengajar. Jakarta: Raja Grafindo Persada.

Secord, P.F. \& Backman. C.W. (1964). Social Psychology. New York: McGraw-Hill.

Siskandar. (2008). Sikap dan Motivasi Siswa dalam Kaitan dengan Hasil Belajar Matematika SD.

Slameto. (2015). Belajar dan Faktor-Faktor yang Mempengaruhi. Jakarta : Rebika Cipta.
Sudjana, Nana. (2008). Penilaian Hasil Proses Belajar Mengajar. Bandung: PT Remaja Rosdakarya.

Suherman, Erman dkk. (2003). Strategi Pembelajaran Matematika Kontemporer. Bandung: PT Remaja Rosdakarya.

Sujarweni, V. Wiratna. (2014). Metode Penelitian: Lengkap, Praktis, dan Mudah Dipahami. Yogyakarta: Pustaka Baru Press.

Syah, Muhibbin. (2004). Psikologis Pendidikan. Jakarta: Rajagrafindo Persada.

Wirawan, S. S. (2002). Teori-Teori Psikologi Sosial. Jakarta: Raja grafindo Persada. 